\title{
Suicide with Very Close Shot Wounds, A Case Report
}

\section{Doaris Ingrid Marbuna ${ }^{\mathrm{a}}$, Abdul Gafar Parinduri ${ }^{\mathrm{b}}$, Rahmadsyah ${ }^{\mathrm{c}}$, Oktafianna Malau $^{\text {, }}$ Jakaria $^{\mathrm{e}}$}

\author{
malauokta@gmail.com \\ Departemen Ilmu Kedokteran Forensik dan Medikolegal Fakultas Kedokteran Universitas Sumatera Utara \\ Medan - Indonesia \\ Departemen Ilmu Kedokteran Forensik dan Medikolegal RSUD Deli Serdang - Lubuk Pakam \\ Fakultas Kedokteran Universitas Muhamammadiyah Sumatera Utara Medan - Indonesia
}

\begin{abstract}
Background: Currently victims of gunshot wound violence are very often found because more and more members of civil society have firearms, both for self-defense and for other purposes. In principle, examination of gunshot wound victims is the same as examination of wounds in other traumas, but there is one specific thing, namely, doctors must know and understand about firearms, ammunition and bullets. Without understanding this, it will be difficult to provide adequate assistance, because injury to the body is ultimately based on these three elements. In gunshot wounds, there are two types of wounds, including incoming gunshot wounds and exit gunshot wounds. incoming gunshot wounds consist of: contact wound, close gunshot wound (near wound), and distant gunshot wound (distant wound).
\end{abstract}

This case report aims to determine the cause of death of the victim, which was found through forensic and histopathological examination, whether the victim died due to suicide, murder or accident.

The case that occurred in Serdang Bedagai on October 6, 2019 at 07:30 WIB, the victim was a 44 years old male, the victim was found dead in his house.

On external examination, he found one incoming gunshot wound to the right side of the head and one exit gunshot wound to the left head. On internal examination, there was blood absorption in the brain and its layers. There was a penetrating wound that entered the right scalp and a penetrating wound on the left side of the scalp.

From the results of forensic and histopathological examinations on a male victim aged 44 years, especially the internal examination of the corpse, it can be concluded that the cause of death of the victim is the destruction of brain tissue which causes loss of function of body organs due to very close gunshot wounds. And the victim allegedly committed suicide.

Key words: gunshot wound, very close gunshot wound, suicide

\section{PRELIMINARY}

Currently, victims of gunshot wound violence are very often found because more and more civilians have firearms, both for self-defense and for other purposes. In principle, examination of gunshot wound victims is the same as examination of wounds in other traumas, but there is one specific thing, namely, doctors must know and understand about firearms, ammunition and bullets. Without understanding this, it will be difficult to provide adequate assistance, because injury to the body is ultimately based on these three elements. A good knowledge of various firearm injuries requires serious attention for a doctor as an examiner including about the basic firearms, the course of the bullet, the trigger, the distance and the process of traveling by the bullet in the body and so on.

A gunshot wound is a wound that is caused by the penetration of a child bullet with the body. If the bullet hits the body, the abnormality that occurs is the resultant of many factors. In the part of the body where the bullets enter, the inner body parts and the parts of the body where the bullets emerge, the deformity is not the same, because the factors that influence them are different. In the case of gunshot wounds, it is necessary to pay attention to:

a. An incoming gunshot wound

b. Gunshot Wound Channels / Child Bullet Channels 


\section{A. AN INCOMING GUNSHOT WOUND}

When someone opens a shot and happens to hit the target, namely the victim's body, then the victim's body will get changes caused by various elements or components that come out of the gun's barrel. Based on the distance of the shot, incoming gunshot wounds can be divided into:

\section{Shoot Wounds (Contact Wound)}

Occurs when the barrel of the gun sticks to the skin. Gunshot wounds are usually star-shaped (stellate / cruciform) because the high gas pressure when searching for a way out will tear the tissue. It looks real especially if there is bone under the skin. In the wound, a barrel wound (bruise) was found where the tip of the barrel was attached to the skin, circular in shape due to a back pounding from the tip of the gun barrel. Gas and gunpowder that is not burned are found in wound tissue (tattoos). High levels of CO, in the form of soot, were found in the wound tissue. Sticky gunshot wounds are usually found in suicides. Therefore, cadaveric spasms are common. Sticky gunshot wounds are often found on the temples, forehead or in the mouth. In general, a gunshot wound in contact is an act of suicide.

\section{Short Wound Very Close (Close Wound)}

Close wounds are often the result of murder. With a very close distance $( \pm 15 \mathrm{~cm})$, you will find bruises, signs of burns, soot and tattoos around the entrance holes. In the target area there were burns due to bursts of fire and hot gas, sooty seams (charcoal), tattoo seams from unburned gunpowder and penetrating wounds with bruised rings on the edges of the wound.

\section{Near Wound}

Wounds less than $70 \mathrm{~cm}$ (about 2 feet) apart will have open wounds, bruising rings and tattoos around the entry wound. Usually because of murder. With gunshot wounds it is very important to check the victim's clothes. It must be matched whether the hole in the victim's body is in line with the hole in the clothing.

\section{Distant Wound}

There are no tattoo seams here, only bullet wounds and bruised rings. Sometimes the ring diameter is slightly smaller than the pupil. The shooting distance is difficult or almost impossible to determine with certainty. Shots from a distance of more than $70 \mathrm{~cm}$ are considered long-range shots, as gunpowder particles do not usually hit their targets again. Neither gunpowder nor gas can carry over long distances. Only the calf can be thrown out more than a few feet. So that the injuries are only caused by the bullet.

There are several characteristics of the wound that can be assessed. Generally, the wound is circular or close to circular in shape. The edges of the wound are ragged. If the calf moves in a non-perpendicular fashion the ragged edges will expand to one side. This check is useful for determining the direction of the child bullet.

In the case of long-range incoming gunshot wounds, it gives great meaning to case investigation. This is because this type of wound eliminates the possibility of shooting yourself, whether intentional or not.

There are 4 exceptions, namely (1) The weapon has been arranged in such a way that it can be fired by the victim from a distance; (2) errors in the results of the examination are due to the shape of a sticky gunshot wound that is 
similar to a long-range gunshot wound; (3) Difficulty in interpretation due to clothing that prevents soot or gunpowder from reaching the skin; (4) The soot or gunpowder has been removed.

This happens when the examiner is not knowledgeable and could have serious consequences for the investigation.

The wounds that appeared in this place (Gunshot Wounds) were caused by factors such as:

- $\quad$ The kinetic force of the child (Projectile).

- The heat temperature of the projectile chicks.

- A burst of fire.

- Gas explosions from gunpowder (In case of outboard gunshot trauma).

- Sparks of unburned gunpowder.

\begin{tabular}{|c|c|c|c|c|c|c|c|}
\hline \multirow{2}{*}{$\begin{array}{l}\text { Type of } \\
\text { wound } \\
\text { Shoot }\end{array}$} & \multicolumn{2}{|r|}{ Bullet } & \multicolumn{2}{|c|}{$\begin{array}{c}\text { Whole } \\
\text { Gunpowder }\end{array}$} & \multicolumn{2}{|c|}{ Burnt Gunpowder } & \multirow{2}{*}{$\begin{array}{l}\text { Hot Gas } \\
\text { Traces of } \\
\text { Barrel }\end{array}$} \\
\hline & Hole & $\begin{array}{l}\text { The seams } \\
\text { are } \\
\text { scuffed }\end{array}$ & Fat seams & $\begin{array}{l}\text { Seam } \\
\text { Tattoo }\end{array}$ & $\begin{array}{l}\text { Kelim } \\
\text { Soot }\end{array}$ & Fire hem & \\
\hline $\begin{array}{l}\text { Far } \\
>70 \mathrm{~cm}\end{array}$ & + & + & + & - & - & - & - \\
\hline $\begin{array}{l}\text { Close } \\
<70 \mathrm{~cm}\end{array}$ & + & + & + & + & - & - & - \\
\hline $\begin{array}{l}\text { Very close } \\
<20 \mathrm{~cm}\end{array}$ & + & + & + & + & + & + & - \\
\hline Paste & + & + & + & - & - & - & ++ \\
\hline
\end{tabular}

\section{B. GUNSHOT WOUND CHANNELS / CHILD BULLET CHANNELS 1,4}

If the bullet in the body does not hit the hard organ (bone), the channel for the incoming gunshot wound and the exit gunshot wound will be straight. But when it collides with a hard organ like bone, the tube can bend.

\section{AN EXIT GUNSHOT WOUND}

This exit gunshot wound is that after the bullet makes a gunshot wound into the gunshot wound, the bullet will hit the skin again from the inside and the skin is pushed outward. If the limit of skin elasticity is exceeded, the skin from the inside becomes torn and eventually a new wound appears, and this new wound is called an exit gunshot wound.

If a bullet after making a gunshot wound enters and hits the bone (hard object), the shape of the bullet changes. The bones that were hit by the bullets would break or sometimes crumble. As a result, when the bullet continued to penetrate and made the gunshot wound out, not only did the bullet change its shape, but the bone fragments were also followed because it was involved thrown by the force of the bullet.

Even these bones sometimes have the power to penetrate as well. This incident resulted in a large and wide exit shot wound, while the shape was not certain. Often the size of an exit gunshot wound is more than the size of an 
incoming gunshot wound. For example, an entry wound along with a contusion ring was approximately $8 \mathrm{~mm}$ in size and a gunshot wound was the size of a coin.

Based on the size, there are several possibilities, namely, if the exit gunshot wound is larger than the entry wound, then usually before leaving the child the bullet has hit the bone until it breaks and some of the pieces come out. These bone fragments can become new bullets that make the exit wound wider. If the exit gunshot wound is the same size as an incoming gunshot wound, this is obtained if the bullet only hits the soft tissues of the body and the penetrating power when it leaves the skin is still quite large.

Injuries that occur can be caused by the following factors:

$\checkmark$ The kinetic force of the child.

Changes in the shape and direction of the bullet, after hitting a hard part of the body (bone).

Bone fragments which can then function as secondary missiles.

If no bruising ring is found around the wound hole, then this is a standard as an exit wound. In the exit wound, you can find the fatty tissue facing outward, although sometimes it is difficult to tell. The shape and size of the exit wound varies, depending on the position of the exit bullet and the speed at which it penetrates the skin. It is easier to confirm if you find bone fragments, especially if you are assisted by $\mathrm{X}$-rays.

There are 3 possibilities that there will be a large exit gunshot wound, namely:

1. An Incoming gunshot wound is smaller than an exit gunshot wound

The factors that cause Shoot Out Wounds to be greater than Incoming Gunshot Wounds are changes in the area of the bullet, due to deformity when the bullet is in the body and hitting the bone, the bullet while in the body changes in motion, for example because it hits a hard part of the body the bullet rotates from the tip -end (end to end) this state is called "tumbling". This straight, irregular movement of the bullet is called "yawing". The bullet breaks into several fragments, these fragments will increase the size of the Shoot Out Wounds, if the bullet hits the bone and the bone fragment is carried out, the bone fragments will create additional tears, thereby enlarging the exit gunshot wound.

2) An incoming gunshot wound is the same as an exit gunshot wound

This occurs when the calf hits the soft part of the body and the penetrating power of the calf is almost the same as the time it was released.

3) An incoming gunshot wound is bigger than an exit gunshot wound

It can be caused by the speed or velocity of the bullet when it is about to penetrate it decreases, so that the damage (the exit hole of the gunshot) will be smaller. It is necessary to know that the ability of the bullet to cause damage is directly related to the size of the bullet and its velocity, namely, the presence of an object that holds or presses the skin in the area. where the bullet will come out, which means inhibiting the speed of the bullet, the exit gunshot wound will be smaller when compared to the incoming gunshot wound.

The difference between an incoming gunshot wound and an exit gunshot wound

\begin{tabular}{cc}
\hline Entry Gunshot Wound & Gunshot Wound Out \\
\hline $\begin{array}{c}\text { Its size is smaller because the bullets penetrate the } \\
\text { skin like a drill at high speed. }\end{array}$ & $\begin{array}{c}\text { The size is larger and more irregular than the } \\
\text { gunshot wound entrance. }\end{array}$ \\
\hline $\begin{array}{c}\text { The edge of the wound curves inwards because the } \\
\text { bullet penetrates the skin from the outside. }\end{array}$ & $\begin{array}{c}\text { The edges of the wound curved outward as the } \\
\text { bullet went out. }\end{array}$ \\
\hline
\end{tabular}


The edges of the wound had abrasion.

The edges of the wound were not subjected to

abrasion.

Fat seams may appear.

There are no fat seams.

he clothes got into the wound.

There is no

On the injury may appear burned, the seams of the

There is no

tattoo or soot.

Fat seams may appear.

Looks like a similar picture cone.

\begin{tabular}{cc}
\hline $\begin{array}{c}\text { Can appear red due to the presence of } \mathrm{CO} \\
\text { substances. }\end{array}$ & There is no. \\
\hline Less bleeding. & There is no \\
\hline $\begin{array}{c}\text { Around the wound, ecchymotic seams appear. } \\
\text { neutrons reveal the presence of tin or iron circle } \\
\text { around the wound. }\end{array}$ & There is no \\
\hline
\end{tabular}

\section{CASE REPORT}

The case that occurred in Serdang Bedagai on October 6, 2019 at 07:30 WIB, the victim was a 44 years old male, the victim was found dead in his house and covered in blood. (Figure 1)

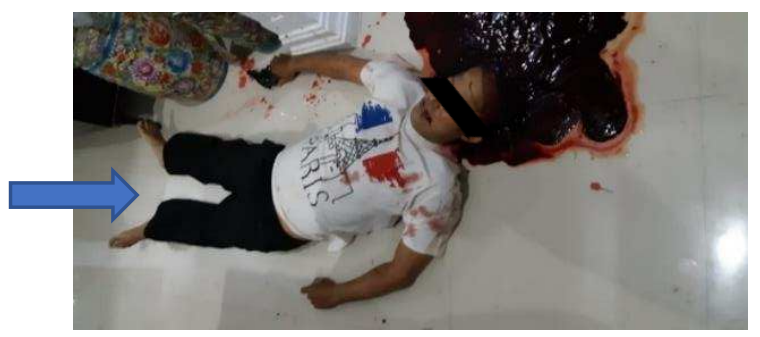

Fig. 1

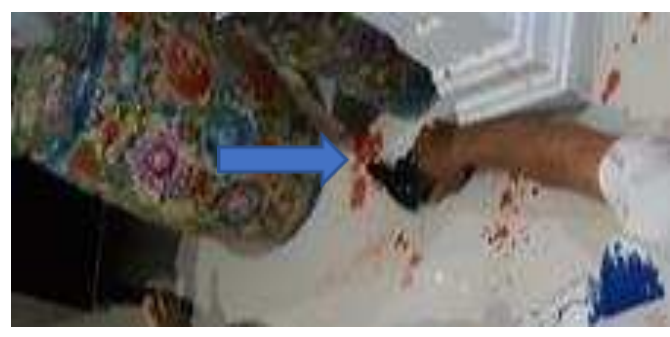

Fig. 2

\section{EXTERNAL EXAMINATION:}

1. On the upper head, a circular wound $1 \mathrm{~cm}$ in diameter is found, with a distance of $6 \mathrm{~cm}$ from the midline of the body, and $9 \mathrm{~cm}$ from the top of the right ear. Around the entrance gunshot wound, it was found black like charcoal with a length of $4 \mathrm{~cm}, 3 \mathrm{~cm}$ wide with a distance of $6 \mathrm{~cm}$ from the centerline of the body and $6.5 \mathrm{~cm}$ from the top of the right ear. Burnt hair was found around the wound. There are scuff seams, fat seams, tattoo seams, soot seams and fire seams, the wound edges point inward, the wound angle is about 100 from the top down.(Figure 3) 2. On the left head, there is an exit gunshot wound, an oblong wound with a length of $1.5 \mathrm{~cm}$, a width of $1 \mathrm{~cm}$, with a distance of $9 \mathrm{~cm}$ from the midline of the body and $4 \mathrm{~cm}$ from the top of the left ear, the wound tissue is pointed outward, the edge of the wound is not average. (Figure 4)

3. On top of the head touch, signs of head fracture are found.

4. There is cadaveric spasm in the right hand. (Figure1)

\section{INTERNAL EXAMINATION:}

1. At the opening of the scalp there is extensive blood absorption from the front of the scalp to the top of the scalp, there is a penetrating wound that goes into the right scalp and there is a penetrating wound on the left side of the scalp, and a fracture of the head from an exit gunshot wound is found size $29 \mathrm{~cm}$ long, $8 \mathrm{~cm}$ wide. (Figure 6) 
2. At the opening of the head bone, $20 \mathrm{ml}$ of blood was found above the thick membrane of the brain, soot was found in the thick membrane of the front of the brain with a length of $11 \mathrm{~cm}$ and a width of $1.5 \mathrm{~cm}$.

3. At the opening of the thick membrane of the brain, blood absorption is found in the thin membrane of the brain with a length of $16 \mathrm{~cm}$ and a width of $10 \mathrm{~cm}$. (Figure 5)

4. When removing the thin membrane of the brain, $3 \mathrm{ml}$ of blood was found on the surface of the brain tissue (Figure 7)

5. In the brain tissue, there are eight bone fragments of the head. After removing the brain tissue, it was found that the weight of the brain tissue was 1,200 grams. (Figure 8)

6. In cutting the cerebellum, found bleeding in the forebrain tissue. After the brain tissue was removed, a fracture was found in the forehead. (Figurer 9)

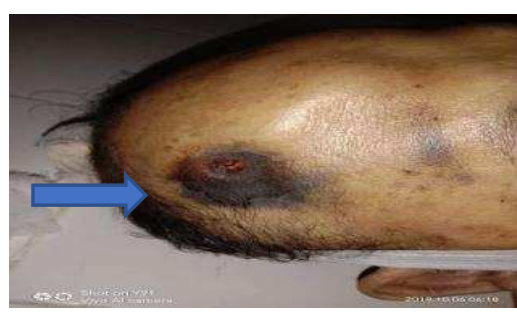

Fig. 3

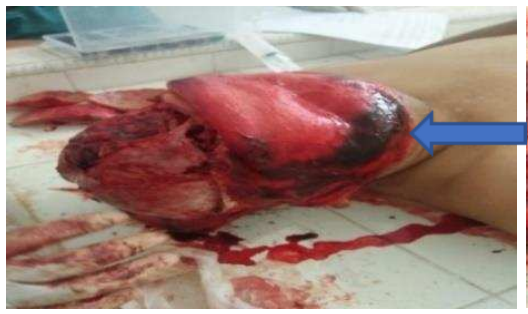

Fig. 6

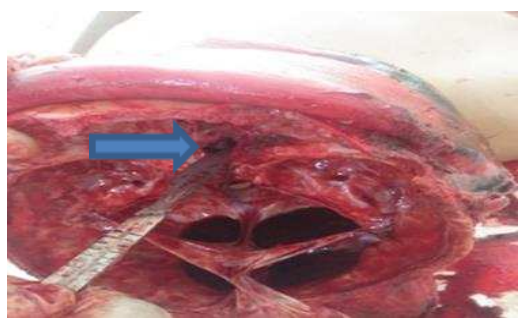

Fig. 9

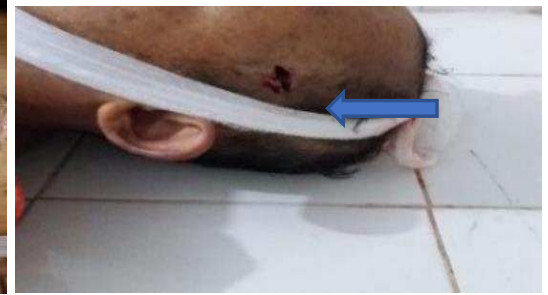

Fig. 4

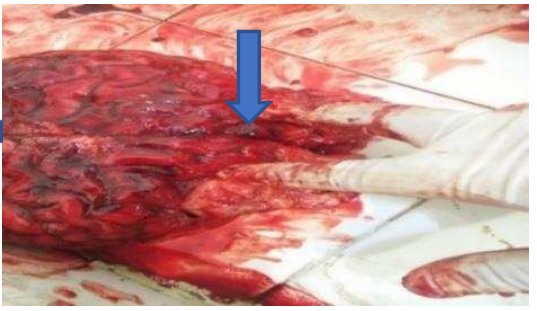

Fig. 7

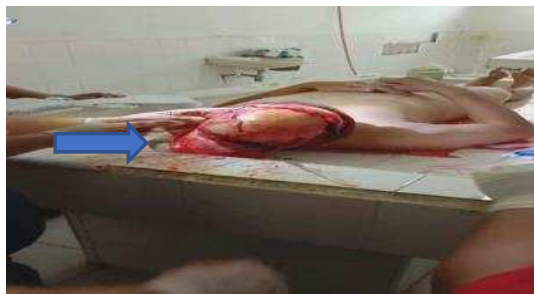

Fig. 5

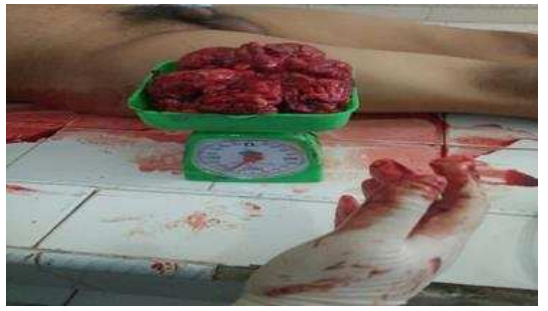

Fig. 8

\section{HISTOPATOLOGY EXAMINATION}

Macroscopic:

Four containers were received in the form of:

- Skin (gunshot wounds), received a piece of grayish brown tissue with an uneven surface, chewy consistency, one time zero point five centimeters in size.

Microscopic:

- Preparation of tissue from the skin (entry gunshot wound), showing a similar picture. The tissue consists of a layer of destroyed epidermis with a round and oval core, smooth chromatin, and eosinophic cytoplasm. On the subepidermal layer, there are groups of black spots. The stroma consists of fibrous connective tissue with infiltrated black patches. Blood vessels within normal limits. 


\section{DISCUSSION}

1. On the upper right side of the head, there is a round wound $1 \mathrm{~cm}$ in diameter, there are blisters, fat seams, tattoo seams, soot seams and fire seams, the skin of the wound edges inward, the wound angle is about 100 from top to bottom, hair around burns indicating that the wound was a very close-in gunshot wound.

2. On the left side of the head, there was an oval wound with a length of $1.5 \mathrm{~cm}, 1 \mathrm{~cm}$ wide, the wound tissue was pointed outward, the edge of the wound was uneven, indicating that the wound was an outward gunshot wound.

3. On top of the head touch, there are signs of head fracture.

4. There was a cadaveric spasm in the right hand, indicating that the victim was suspected of committing suicide.

5. At the opening of the scalp, blood infiltration is found starting from the front of the scalp to the top of the scalp, skull fractures are found, at the opening of the thick membrane of the brain blood is found in the thin membrane and blood is found on the surface of the brain tissue. then in the brain tissue, eight fragments of the head bone were found that tore the brain tissue. After the brain tissue is removed, a fracture of the forehead is found. In this examination, it shows the channel of the bullet that enters the cavity of the head through the brain tissue to exit the cavity of the head. The tearing of the brain tissue causes the loss of all the functions of the body organs which results in death.

\section{CONCLUSION}

1. In accordance with the findings obtained from the results of forensic and histopathological examinations on a male victim aged 44 years, especially the internal examination of the body, it can be concluded that the cause of death of the victim is the destruction of brain tissue which causes loss of function of body organs due to very close gunshot wounds.

2. From the results of the Forensic Medicine examination, the victim is suspected of having committed suicide.

\section{REFERENCES}

1) Dahlan S, 2000, Ilmu Kedokteran Forensik Pedoman bagi Dokter dan Penegak Hukum, Cetakan Ke 3, Universitas Diponegoro Semarang, p. 93-106.

2) Amir Amri, 2007, Rangkaian Ilmu Kedokteran Forensik, Fakultas Kedokteran Universitas Sumatera Utara, Medan, Edisi ke II cetakan ke 3, p. 91-103.

3) Gani MH. 2002, Ilmu Kedokteran Forensik, Bagian Kedokteran Forensik. Fakultas kedokteran Universitas Andalas, Padang. P. 50-54.

4) Ilmu Kedokteran Forensik. 1997, Bagian Kedokteran Forensik, Fakultas Kedokteran Universitas Indonesia, Jakarta. p. 44-80.

5) Bernard Knight, Forensik Pathologi, second edition, Arnold, New York 1996, Hal 243-73.

6) Nandy A. 1996, Principles of Forensic Medicine. New central book agency (p) ltd. Calcuta.India: p. 240-65.

7) Hamdani N. 1992, Ilmu Kedokteran Kehakiman, Edisi II, PT. Gramedia, Jakarta, p.109-16.

8) Idries Munim Abdul, 1997, Pedoman Ilmu Kedokteran Forensik, Edisi Pertama, Jakarta, p. 44-80.

9) Chada PV. 1995, Catatan Kuliah Ilmu Forensik dan Toksikologi, Edisi V, ahli bahasa J. Hutauruk, Widya Medika, Jakarta, p. 76-83.

10) Wahid, S.A. 1973, Patologi Forensik. Kematian akibat luka tembak. Dewan Bahasa dan Pustaka Kementerian Pendidikan Malaysia, Kuala Lumpur, p. 192-228 